\title{
THE AESTHETIC RECEPTION OF THE QURAN IN INSTAGRAM: Variations, Factors, and Religious Commodification
}

\author{
Rizal Faturohman Purnama \\ Universitas Islam Negeri Sunan Kalijaga Yogyakarta, Indonesia \\ E-mail: faturohmanrizal4@gmail.com
}

\begin{abstract}
This research discusses the aesthetic reception of the Quran in Instagram including various forms, appearance factors and commodification. This research is included in the qualitative study using Ahmad Rafiq's reception theory. Using descriptive-analytical method, the study found variations of the Quran's aesthetic reception in Instagram which are in the form of verse continuation and the Quran recitation. The background factors of the Quran's aesthetic reception in Instagram include normative factors the Quran's verses showing kindness to those who teach and practice it; historical factor i.e. the past reality related to the Quran's aesthetic reception done by the Arab community; and social factors showing high passion of self-expression in preaching. Instagram as a social media has modified the Quran's aesthetic reception with several available facilities and featuresthat enables its users to express themselves concerning the identity of religious piety and economic commodities through several contents related to the Quran.
\end{abstract}

Penelitian ini membahas tentang resepsi estetis atas Al-Qur'an dalam media sosial Instagram yang meliputi ragam bentuk, faktor kemunculan serta komodifikasinya. Penelitian ini termasuk pada studi kualitatif serta menggunakan teori resepsi ala Ahmad Rafiq. Dengan menggunakan metode deskriptif-analitis, penelitian ini sampai pada temuan, yakni: variasi resepsi estetis atas Al-Qur'an dalam ruang media sosial Instagram yang eksis dalam 
bentuk konten-konten berupa sambung ayat dan praktik tilawah Al-Qur'an. Faktor-faktor yang melatarbelakangi kemunculan resepsi estetis atas AlQur'an dalam ruang Instagram meliputi faktor normatif, yaitu adanya sejumlah ayat Al-Qur'an yang menunjukan kebaikan bagi orang-orang yang mengajarkan dan mengamalkannya; faktor historis, yaitu adanya kenyataan terdahulu terkait resepsi estetis Al-Qur'an yang sudah dilakukan oleh masyarakat Arab; dan faktor sosial, yaitu tingginya gairah ekspresi diri dalam tujuan berdakwah. Media sosial Instagram telah memodifikasi resepsi estetis atas Al-Qur'an dengan sejumlah fasilitas dan fitur-fitur yang tersedia, sehingga memungkinkan bagi para pengguna Instagram untuk mengekspresikan diri yang menyangkut identitas kesalehan beragama dan komoditas ekonomi melalui sejumlah konten-konten yang berkaitan dengan Al-Qur'an.

Keywords: aesthetic reception; Instagram; Quran; social media

Received: July 1, 2020; Accepted: October 8, 2020

\section{Introduction}

As the Islamic holy text, the Quran has a complicated history that led to a long and exciting discussion. However, Ahmad Rafiq states that when talking about the Quran, there is still minimum discussion on the reception (in Syamsuddin (ed.) 2012, 66-67), moreover the one related to social media, especially Instagram. In fact, social media space including Instagram, is a place that represents the community's religious practices, especially the relationship between the Islamic community and the Quran (Mahmudah 2017, 197). Thus, it is even essential to conduct a study on the Quran related to social media, to see the interaction between the Islamic community and the Quran in this modern era. Instagram was chosen as a space to see the aesthetic reception of the Quran because it is a social media in which millennials love to express their religious aspects aesthetically.

So far, previous studies tend to highlight four aspects; first, a study that generally highlights several Islamic issues in social media (Irwandani 2016; Nasrullah 2016; Wibowo 2019), there is also one focusing on the effectiveness of Islamic knowledge transformation in social media (Becker 2009; Gräf 2007, 2009; Mariani 2013). Second, studies focusing on da'wah and social media themes (Aminuddin 2017; Avifah 2017; Dewi 2019; Ismail, Abidin, and Fatoni 2017; Romario and Aisyah 2019; Zahra, Sarbini, 
and Shodiqin 2016). Besides, there is a general view of ulama (scholars) on recent technology (Larsson 2016) and social media's role in democratizing religious knowledge (Anderson 2003; Bunt 2003; Piela 2013).

Third, there are studies concerning the various aspects of the Quran reception in society (Fadlillah 2019; Hasan 2020; I. L. Jannah 2018; M. Jannah 2017; Khosim 2019; Nurfuadah 2017; Pahala 2018; Prasetya 2019; Rurin 2018). The last aspect is study of the Quran's reception on social media (Fahrudin 2020; Mahmudah 2017; Masrurin 2019). The Quran's reception was also discussed by several anthropological researchers (Rasmussen 2010; Graham 2001; Rafiq 2014). This shows that Muslim life in social media is an exciting object for anthropologists in seeing piety in digital world. However, in fact, the amount of study focusing on social media as a reception room is still insufficient. Some of the researchers in this field focused on the Quran that circulates on social media only, yet it did not discuss the Quran visualization and reception factor. Based on these four trends, studies on the variety of visualizations and the appearance factors of the Quran reception in social media, specifically in Instagram, should be more comprehensively studied.

The study is relevant to complemet the previous studies. To make it focused and systematic, the study will be outlined based on three formulations: (a) how does Instagram become a public reception room for the Quran? (b) what is the Quran's aesthetic reception in Instagram? (c) why does the Quran's aesthetic reception appear in Instagram? This paper assumes the Quran's aesthetic reception on Instagram comes with diverse visualization surrounded by several specific factors or objectives or motives. Clark states that nowadays, we live like what Russel claimed as a remix culture. A technological system allows every society to adapt and evaluate existing cultures (Kammer 2012, 4). This will have implications for transforming the Quran's reception practices on social media with cultural remix.

This study includes in qualitative and library research studies. The method is descriptive-analytical which first describes the aesthetic reception forms of the Quran in Instagram, then critically analyzes the emergence factors, and the last, explains how Instagram's existence in transforming public reception over the Quran. The data in this study consists of primary and secondary data. This study's primary data are several contents related to Islamic memes and practices uploaded on Instagram through individual 
accounts. Simultaneously, the secondary data is a wide range of literature relevant to the primary data.

Furthermore, the study used Ahmad Rafiq's reception theory to see how the Quran is in Instagram. He divides the Quran's reception into three i.e. exegesis, aesthetic, and available receptions (Rafiq 2014, 14-15). This discussion will focus on aesthetic reception, it is done in aesthetically releasing experiences (ilâhiyah) (Rafiq 2014, 14-15), such as tilâwah, mujawwad, and aesthetically nuanced in Instagram. The analysis will use media analysis theory to see the impact and purpose in that case. A number of these sets of methods are expected to present an ideal discussion in this study.

\section{Reception of the Quran and Social Media}

The reception is an expression of acceptance of something. It comes from the word recipes (Latin), which means accepting or welcoming the reader to the text. Terminologically, it is a science about the beauty of the reader's response to a literary work. In general, reception can also be said as a study focusing on the reader's role in responding, reacting, and welcoming a particular literary work. This aims at analyzing how the forms of response or the reader's role as the consumer of literary work in determining the associated meaning and the values (Fathurrosyid 2016, 221). Therefore, the reader's position becomes significant in determining the meaning and value of a literary work, in other words, the form of the text depends heavily on how the reader respond to the text to make it more meaningful (Iser 1978, 20).

The Quran is also a relevant literary work as an object of reception studies. The meaning of reception of the Quran is a person reacting to the Quran by accepting, responding, utilizing or using it either as a text containing syntax arrangements or as a booked mushaf that has meaning or a set of loose words that have a specific meaning (Syamsuddin (ed.) 2012, 73). In essence, the Quran's reception has a focus on the reader in constructing the meaning of the holybook as a literary work, then "internalizing" the Quran. The reception theory's basic assumption is that each literary work has two areas of meaning, namely the meaning itself and its significance.

Dailey said that social media is online content that is easily accessible. The important thing about this technology product is the shift in the way people know information and news (Suardi 2016, 83-84). Its existence can 
build widespread faceless interaction. Its use is not only limited to communication but also for the media of da'wah, the dissemination of religious content and the Quran recitation. In the context of the Quran development, social media plays significant role (Watie 2016, 70). In other words, the spread of the Quran in social media is unlimited. We can find it in Facebook, Instagram, Twitter, Line, Whatsapp, Telegram and Youtube, which are very accessible and fast. All come with their respective versions (Fauziah and Miski 2019, 127-28).

One of the most popular social media nowadays is Instagram. Instagram makes the users easy to share photos, videos, and social networking services with their followers (Budiargo 2015, 48). Instagram was founded by Kevin Sysfrom and Mike Krieger in October 2010. The photos on Instagram tell the user's current situation and are mementos to see in the future. Instagram users expect a response from their followers to comment and like the uploaded photos or videos. Judging by the type of social media, Instagram belongs to social media sharing, a site that allows users to store and share images, podcasts, and videos online (Nasrullah 2016, 44).

The large number of social media users makes the reception of the Quran very widespread. Take the example in Indonesia, people prefer to seek for the Quranic study from social media than from the ulama (scholars) directly (Lukman 2018, 99). It also explains Indonesians' digital literacy efforts amid the lack of literacy awareness, as revealed by Lukman that social media helps to learn thoroughly on the broader realm (Lukman 2018).

Social media provides the audiovisuals of the Quran. It contains social dimension and has become an alternative to Indonesian society in studying the Quran because it is more straightforward and suitable for its users (Hamdan and Miski 2019, 263). Social media is also a free-expression platform (Ahmadi, Hefni, and Mutrofin 2019, 86-87). On the other hand, social media defocus the facts that there are no more strict provisions on who should speak and teach about the Quran (Miski and Hamdan 2019, 42).

The Quranic content in social media can encourage its Muslim users to read the Quran everyday (Nisa 2018, 26-27). Unconsciously, social media has changed the religious practices of Muslims, mainly social media users. Muslims' social interaction in online space changes since they can follow their favorite figures and can virtually communicate with them whenever (Slama 2018, 4-5). 


\section{The Role of Digital Media as a Reception Place for the Quran}

The role of digital media as a reception place, which in this case includes social media, at least starts from the dynamic development of the communication tradition among people in spoken form. Then, it grew into the written form until recently when several digital media appear (Nasrullah 2018, 3-4). Digital media's role, especially social media, has significant implications as a channel for expressing public's culture (Nasrullah 2018, 26). Therefore, in the era of cyberculture, the use of certain digital media has become a habit in society, and this may also be related to the practice of the Quran's reception for the Islamic community in particular.

Media is considered as the main place for society in obtaining religious information and others, including those related to the Quran, making its existence prominent. Public's high interest in obtaining variousinformation through the media challenges some parties, especially in the context of Islamic da'wah, to be able to package religious content including the Quran creatively so that it attracts public's interest. Furthermore, the media is also considered a strategic social pillar, so it has a central role in human life (Ishaq 2013, 144-46). It means that media utilization is an assurance, and these results in the appearance of the Quran's reception through a certain number of media spaces.

Digital media with many kinds and characteristics are relatively superior, that make it the right place for the Quran's receptionsince it is in high demand nowadays. This variant of the Quran reception is easy to trace in the digital media space. Digital media's capability has made the Quran accessible through several visual, audiovisual, and other contents, depending on the size of the digital media itself in accommodating the uploaded content. The large spread of interesting uploaded content has now enlarged the role of digital media. They provide space for the Quran's reception expression by the Islamic community as the impact of the advanced technology.

\section{Instagram as a Quran Reception Room}

Social media plays essential role in building popularity in society, especially among youth as the target audience. Of all social media platforms, Instagram has a dominant role in popularizing public figures. One survey of e-markers showed that the audience of online-based digital video in Indonesia was relatively high, reaching approximately 77.3 million at the end of 2018. This number is predicted to increase every year. One of the 
most-watched sources of video is Instagram, which is an online-based video and image sharing application (Penonton Video Digital Indonesia Diprediksi Mencapai 100 Juta Orang pada 2021 | Databoks n.d.).

Since its release in 2010 to date, Instagram has a growing number of active users that does not have age limit. Photos and videos on Instagram become the contents that have many viewers as a sign that there is no privacy in social media. Many Islamic digital environments have made researchers choose different analytical topics. Thus, the selection of accounts in digital media is different among researchers depending on the interest and purpose (Bunt 2003, 7). Considering the analysis Bunt offered, the researcher selects some Instagram accounts that were deemed relevant, and contained issues related to the aesthetic reception of the Quran.

In Indonesia, the content of everyday-life photos and videos related to the Quran gains attention. For example, one of ITB students who is also the imam of Salman Mosque in ITB named Muzammil Hasballah attracts 3.6 millions followers. His contents are mostly the Quran murattal (one type of recitation). (Muzammil Hasballah (@muzammilhb), Instagram photos and videos n.d.). There is also @taqy_malik account which popularizes the Quran murattal among youth in social media. His account has around 2 millions followers. In addition, both figures also shared their Quran reception and daily life on YouTube channel named Muzammil Hasballah with 1.56 millions subscribers (Muzammil Hasballah - YouTube n.d.) whereas Taqy Malik's channel has 496 thousands subscribers (Taqy Malik YouTube n.d.). While sharing their moment with the Quran, they also got many responses from its followers or viewers, thus providing indirect learning. Both accounts are relatively famous on social media with a variety of content that is always related to the Quran, also inspire those who watch it and enable interactionthrough social media.

In the context of the aesthetic reception of the Quran, Instagram does not only serve videos. It also builds more interaction with their audience or followers. Which is useful to maintain their existence. This is in line with Bunt's statement that the digital age has opened up a new space for the digitalcommunity to express their existence (Bunt 2009, 2). Researchers recorded other Instagram accounts (besides the two mentioned above) in which reception of the Quran showed significant response. There are @Boim and @bahanan93 each followed by around 433 thousands followers (Ibrohim Fadlannul Haq's (@boim97) profile on Instagram, 299 posts n.d.) and 767k (Salim Bahanan (@bahanan93), Instagram photos and videos 
n.d.). The number of followers owned by these accounts is relatively high compared to other Instagram users.

Instagram is a photo and video sharing medium included in Social Networking Service (SNS). Therefore, images and captions are essential elements for building interactions with other Instagram users. In this context, each account does not just share the latest photo and video about general information on Instagram, but also post daily-life photos and videos. Each photo is usually followed by a caption about a verse quote from the Quran, or a persuasive sentence about reading or memorizing the Quran.

Snapgram or InstaStory on Instagram is also a significant feature for those famous accounts to encourage their followers to keep reading the Quran. For example, in some InstaStory presentations, they show the murattal (recitation) of the Quran while driving a car. This gives a lesson to the followers that Muslim is obliged to read the Quran everywhere. Furthermore, they recite the Quran without looking at the text to implicitly encourage the viewers to memorize the Quran as well. Another example is the InstaStory aired every Friday which always contains a reminder of reading surah al-Kahf. The accounts use the term "al-Kahfi Reminder".

The communication language used in these Instagram accounts is the one used by young generation which is easy to understand. This kind of thing makes the interaction among other Instagram users closer. In this context, those Instagram accounts have already showed the Quran's reception for their followers to respond or learn. Therefore, Instagram becomes the relevant Quran's reception room and is widely used by young people to share the aesthetics of the Quran.

\section{Instagram and the Transformation of the Community Reception Over the Quran}

The Quran is the best product of literature that has full of meaning. Because of its strong-energy content, when it is verbalized or non-verbalized, it positively influences its readers (Riyadi 2014, 47). The verbal or nonverbal dimension practiced aesthetically by the reception actors, especially the Arab community as a first-generation for the Quran's reception who is well-civilized with literature, were judged to be factual pioneers of the Quran's reception that have been dynamic and exist. This proposition can at least be affirmed by looking at the study entitled The Aesthetic Reception of 
the Quran as Reflected in Early Muslim History by Navid Kermani which found that Arab society and its literary culture were the starting point for the emergence of receptions for the Quran, especially aesthetically (J. Boullata (ed) 2000, 255-72).

On the other hand, the historicity of the Quran's revelation is also the reason for the dynamic reception of Muslims from time to time, exactly at the reception of philosophical or pragmatic spheres (Kamal 2015, 18991). The Quran, which comes as scripture with a piece of science that is part of its miracles, makes every human being curious to further comprehend it. So, this may be the cause for the Quran from time to time to never stagnate its reception practice. In general review, it is probably relevant to quote what Ahmad Rafiq noted regarding the purpose of the Quran reading, here considered as the background of the Quran's reception. He mentions that reading the Quran will be considered as worship, instruction, and legitimacy tools (justification). Functionally, reading the Quran has a profane orientation (Mustaqim 2015, 42-43; Rafiq 2004, 3-5).

Beside the purpose of its reading, the reception of the Quran from time to time is also considered very closely related to the process and cycle of transmission and transformation. Fadlillah's study at least highlights how strong the implications of the transmission-transformation dimension in the context of the Quran reception. It will be dynamic if there is continuity among reception actors from one generation to another in the realm of transmission-transformation based on the history of the Quran's virtues. Therefore, there is a creative process in the Quran's reception which results in the emergence of its practice both informatively and performatively (Fadlillah 2019, 127). The practice of the Quran's reception related to its creative process on the next occasion is at least considered to be the cause of its practice in various spaces. It is then in line with the Quran's jargon șâlih li kull zamân wa makân.

\section{Variations of the Quran Reception on Instagram}

The reception on Instagram is very varied. The visualization in the form of audio and video is the main point in Instagram. These variations are conceptualized into images displayed through a certain amount of digital media by their creators. The emergence of lots of visualization practices these days is inseparable from the trend of 'cyberculture' as a new culture that strongly relates between humans and the utilization of 
technology in the sustainability of its social practices in virtual spaces, including social media. This visualization practice can at least be represented and seen through the emergence of very trendy memes in social media, Instagram in particular. The meme itself is a form of visualization consisting of images or illustrations and text, which appears as an expression of its creator in response to certain things (Nasrullah 2016, 11424).

The form of the Quran's reception on Instagram also includes the 'Islami' meme, as Islamic values content with the Quran as one of the sources. The emergence of the Quran reception on Instagram through the practice of visualization is the function of social media itself as a medium to spread the religious teachings (da'wah) (Annazilli 2018, 28). One of ways to spread religious teachings is through visualization content such as pictures, depending on how the interest and trend at the moment (Wibowo 2019, 342). This indicates that the appearance of the Quran reception in Instagram is inseparable from da'wah factor leading to the purpose of education and the expression of spirituality by various communities, especially millennials.

The aesthetic of the Quran's reception in Instagram can be easily found in several accounts which intentionally post Quran-themed contents in particular. The reception is presented in the form of memes containing educational content. It is, for example, shown in tahsîn and tilâwah, which are aesthetically created to impress and appeal itsviewers or users. There is also visualization of the Quran Mushaf or snippet of verse/s decorated with text narration, pictures, and the like. What is more interesting from the Quran's reception in Instagram is that they are aesthetically expressed since it is accepted by both users and connoisseurs of Instagram content (Rozaq 2019, 208). 
Picture 1

Content of the Quran on Instagram

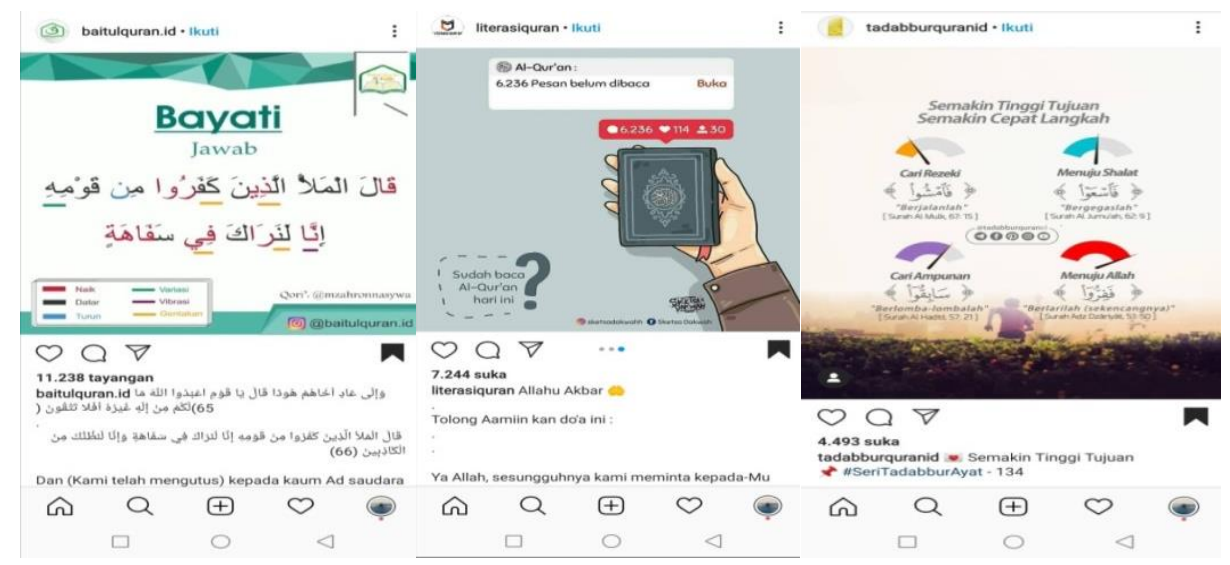

There are five language systems being the object of the Quran's reception i.e., sound (font), word (morpheme), sentence (syntax), meaning (semantic), and function (pragmatic) (Rafiq 2018). The five objects undergo their reception process in terms of reception style, namely, exegesis, aesthetic, and functional receptions (Rafiq 2018). In this discussion, the object will be seen in aesthetic reception style. Some of the aesthetic reception variations of the Quran in Instagram are as follows:

\section{Murattal al-Qur'ân}

Another aesthetic reception of the Quran in Instagram can be seen from the phenomenon of reading the Quran by tartîl (murattal) that is the slow recitation with improvised sounds and rhythms in such a beautiful way. This can simply be considered as the art of reading the Quran and is commonly accepted by the majority in various spaces and times (Suryati 2017, 48), including Instagram. In Instagram, the art of reading the Quran can be found through various uploaded video related to the practice of murattal al-Qur'ân recited by youths. Generally, the activities of reading the Quran aesthetically can be found offline and online through digital media, including SNS. The proof of fidelity expressed by beautifully reciting the Quran as a form of aesthetic reception can at least be seen from the phenomenon of reading the Quran on social media by several Qurrâ' (the Quran reciters) (Masrurin 2019, 190). 
Picture 2

Murattal content on Instagram

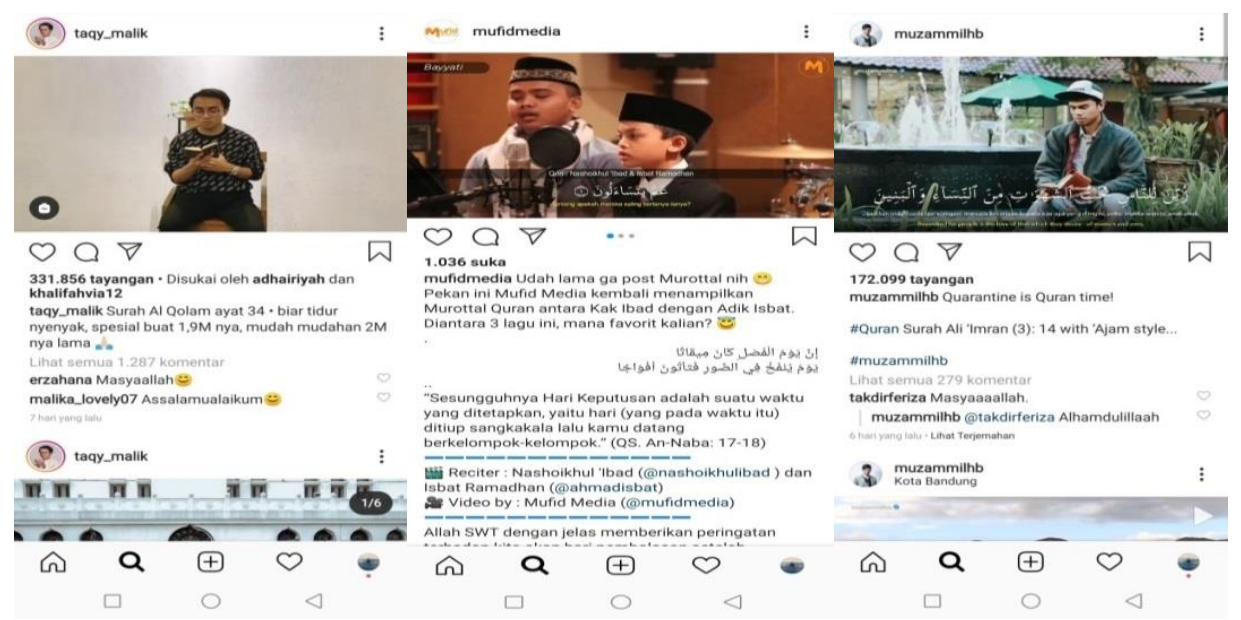

Furthermore, in Instagram, the Quran's aesthetic reception can be found on several accounts, say, @taqy_malik which has 2 millions followers (\#JuraganSaffron (@taqy_malik),Instagram photos and videos n.d.); @muzammilhb which has 3.6 millions followers (Muzammil Hasballah (@muzammilhb), Instagram photos and videos n.d.); and other accounts such as@boim97 that has 433 thousands followers (Ibrohim Fadlannul Haq's (@boim97) profile on Instagram, 299 posts n.d.) and @bahanan93 with 767 thousands followers (Salim Bahanan (@bahanan93), Instagram photos and videos n.d.). These accounts have similar content for example the Quran's aesthetic posts and their respective daily lives so that they can interact with the followers. In addition to direct searches of several relevant accounts, the Quran's reception in the form of murattal (recitation style) can be discovered through hashtags on Instagram such as \#murottalquran, \#murotalquran, \#tartil, and other similar themes. The high number of aesthetic receptions in the form of murattal al-Qur'an is a result of the increasing interest on the art of reading/reciting the Quran or the so-called tilawah al-Qur'ân. This is believed as the peak's sign of sound art in Islam which contains several benefits (Suryati, Simatupang, and Ganap 2016, 68). It is also proven with many Islamic generation in Indonesia particularly, competing in creating content and uploading it to their Instagram account. Meanwhile, this phenomenon is not limited only to its creators as a 
reception party, the uploaded content is also accepted by its loyal audiences which can be seen from the comments section on those accounts.

The variants of murattal al-Qur'ân found in Instagram are not limited to content directly displaying the reciters or snippet of the Quran's verses. There are also contents presenting visualized posts which were completed by beautiful recitation of murattal al-Qur'ân. Regardless, the idea of murattal here is considered as the forms of the Quran's reception in aesthetics term. This fact shows that even if the Quran is derived in Arabic, the non-Arabic native speakers can still accept it by appreciating the beauty of the Quran. Moreover, one verse in Q.S. al-Muzzammil [73]: 4 contains the advice to read the Quran in tartîl (reciting with a slow measured rhythmic tones) (Matondang 2018, 6).

\section{Mujawwad al-Qur'ân}

Discussing about tilâwah al-Qur'ân, the aesthetic reception of the Quran is also included in the form of mujawwad (Qirâ'ah) i.e. reading and performing it beautifully or melismatis (ornamentation of melodies). This art of reading the Quran is commonly accepted by the society and is easy to find in various places and times, mainly at the event of Musabaqah Tilawatil Qur'an (MTQ) (Suryati, Simatupang, and Ganap 2016, 68-69). The emergence of the Quran's aesthetic reception in the form of mujawwad is the result of connection between aesthetic and religious tradition in the society's life. Another reason is because of the assumption that the Quran is a work containing the beauty and enthusiasm of people in appreciating their religion's scripture (Jannah 2017, 93). So, it can be further explained that the aesthetic reception of the Quran in mujawwad style is exist because some people who give attention to the beauty side of the Quran.

We can find the Quran recitation in mujawwad style in several Instagram accounts of qurrâ' (reciters) from Indonesia. They are the people who are well-experienced in the world of tilâwah al-Qur'ân and are considered professional. There are several pioneers of qurrâ' in Instagram such as@darwinqori, @salmandjiharkah_q.a, and @syamsurifir. These accounts belong to each individual and are privately managed. Besides those qurrâ's accounts, there are also severalaccounts which usually re-post other contents, for example @sang_qori, @qori.channel, @qori.tv, and it is completed by using the hashtag \#qori_qoriah_indonesia, \#qori_qoriah_indonesia_hitz. Usually, the qurrâ' record themselves reciting 
several verses of the Quran in mujawwad style, then it will be uploaded to their accounts. They complete the post by writing the inspiring and relevant caption which, they think, will gain much attention from their followers.

Picture 3

Mujawwad content on Instagram

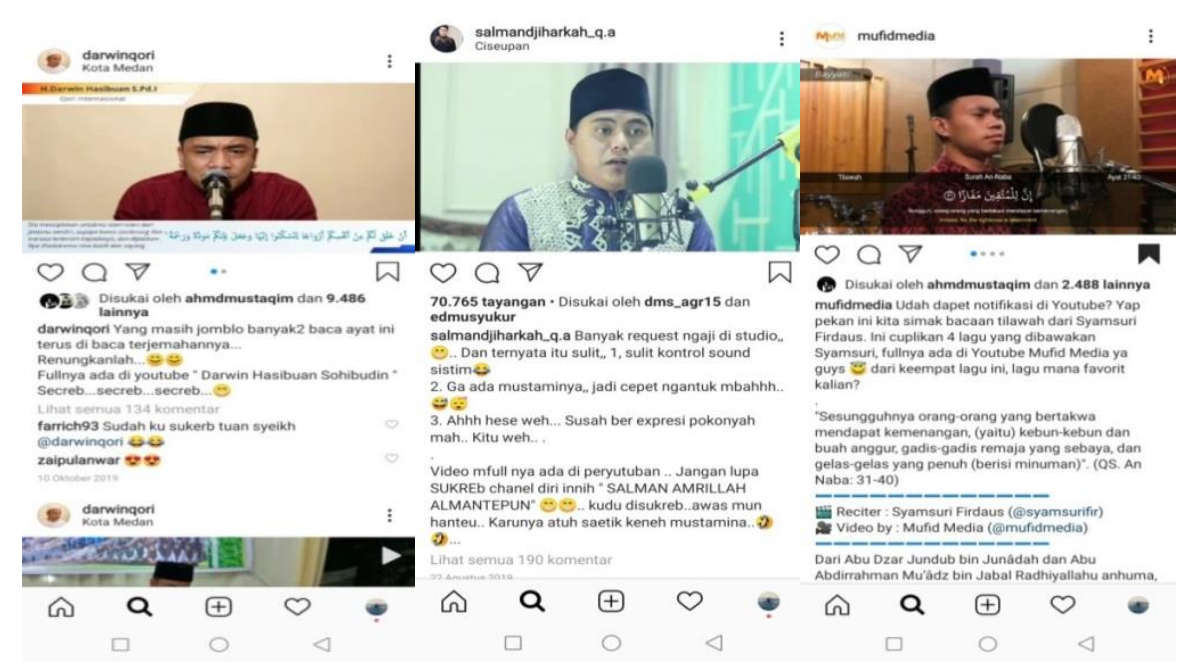

Fundamentally, social media is dialogic, in the sense that it allows the reception exchanges through comments section (Masrurin 2019, 196) proving that there really is the Quran's aesthetic reception in the Instagram space. As a response from the followers, they oftenimitate the reading style (mujawwad) of the qurrâ' and upload their own video version in each personal account. This responseindicates a pattern of continuity of the Quran's aesthetic reception. Therefore, variation of the Quran's aesthetic reception in Instagram is a result of da'wah effort to familiarize the art of the Quran using digital media, specifically cyber one (Nurhayati, Junaedi, and Sahliah 2019, 108).

\section{Verse Connect Feature}

Instagram's existence as a popular SNS is one medium in cyberculture or screen culture that connects subjects in virtual space. Instagram received an enthusiastic response from young people in particular. This proves that the exciting thing that happened in the 21st century was the phenomenon of re-identity by urban youth shown in their high passion in accepting the 
digital communication revolution (Heryanto 2015, 1), including Instagram as a social media. The use of social media that is strongly related to the issue of identity is also included in the religious realm. Praxis-wise, the constructed identity is also related to the expression of righteousness shown through the uploaded visual content (Nasrullah 2011, 228). The use of Instagram which is oriented to show people's piety turns it into one of new places to express the reception of the Quran, because virtuous side of people is revealed through their way of receiving the religious sources i.e. the Quran.

Furthermore, Instagram as a new room for the Quran's reception is an inevitable form of the relationship between the Quran considered as sâlih li kull zamân wa makân and digital media that can accommodate the creativity of its users in the creation of virtuous life. Instagram has significantly contributed to the religious realm, especially when it comes to the strength of its visibility so that the components of religious teachings will continue to exist in the ever-changing development of the times (Aulia 2017, 139). In the context of globalization, the meeting between Islam and modernity has also created a relationship between the two concerning the realm of creativity in a highly dynamic, implicative, adaptive, and useful spectrum (Rozaki 2013, 210).

\section{Picture 4}

Verse Connect feature in Instagram

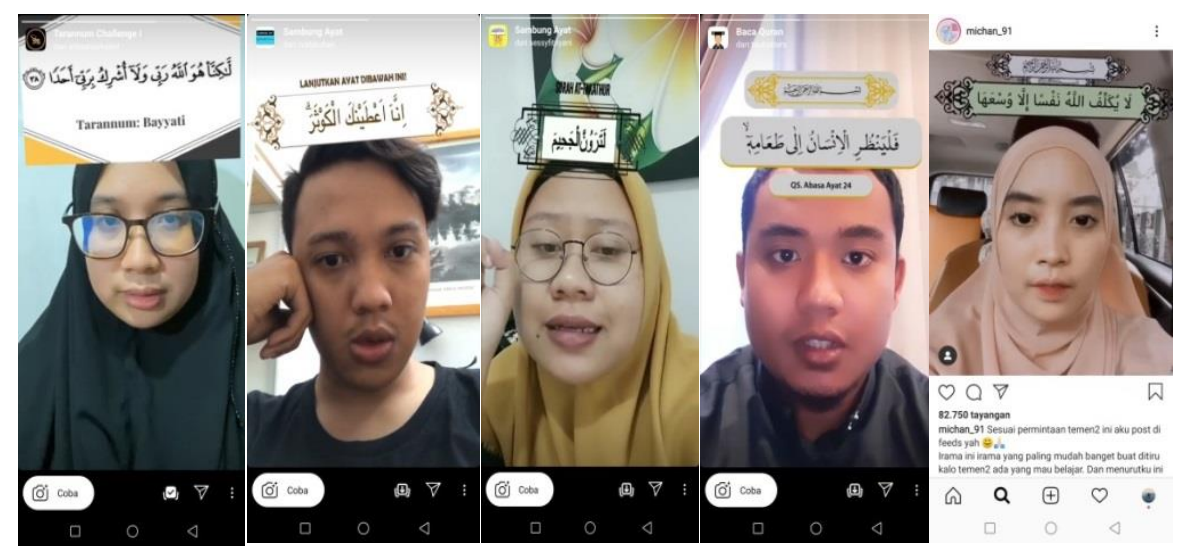

Instagram, in this case, is a social media that gives its users the freedom to create exciting content and features that are relevant to what is 
trendy and in demand, such as the Verse Connect feature. The feature is now a trend among Instagram users who are interested in the practice of reading the Quran. The users compete to upload the content of the feature as a form of self-expression. Moreover, the various forms of the feature are created due to the "competition" in developing similar features to appeal other users. Social media activities are successful if the narratives, icons, and symbolic representations resemble the components that dominate contemporary popular culture related to the consumptive realm (Lim 2017, 47). Because social media is online basis, there will always be new produced things, so the old features sooner or later will be replaced by a new one. Only few of them can last longer (Imron 2019, 261-62).

\section{The Aesthetic Reception Factors of the Quran on Instagram}

The Quran is the word of God and is a sacred text, which is believed to be a holybook. The book, as God promised, will be protected directly by Allah mentioned in His words "We are the one who sent down the Quran, and we are the one who guards it" (Q.S. al-Hijr [15]: 9). Muslims are also obliged to maintain the sanctity of the Quran by memorizing and reading the Quran. Thus, substantially and textually, the Quran will not damage and change, but as a written text, it enables people to have varied receptions. One of the Quran's receptions is aesthetic reception.

The Quran in Instagram was usually recited by public figures who show their own aesthetic reception. Talking about Instagram's use as social media, it goes hand in hand with the orientation and purpose of its user to understand the content correctly (Putra 2020, 19-20). One form of aesthetic reception is found through the uploaded content of videos, photos, and captions. Referring to Ahmad Rafiq, aesthetic reception is a process of acceptance using eyes and ears, art experience, and a taste of an object (in Syamsuddin (ed.) 2012, 73). The factors seen in these analyzed accounts refer to Ahmad Rafiq's theory based on the appearance of the reception. There are several factors related to the appearance of aesthetic reception of the Quran by observing individual accounts; they are:

\section{Normative Factors}

Taqy Malik and Muzammil Hasballah's Instagram accounts upload video and photo content about reading the Quran along with the caption of religious normative values, both in the form of evidence of the Quran, hadith, and the story of the companions. It shows that they are encouraged 
to share religious evidence and upload the content revealing the Quran as the highest artistic value. Mukti Ali argues that the Quran contains an extensive dimension and three of them are art, science and religion (in Handayana and Rezi 2018, 137). Therefore, the art and understanding of religion within the uploaded content in the mentioned account showed the Quran's reception in such a way.

If we learned about history, there was the Prophet's companion reciting the Quran in a melodious and amazing voice such as Abû Mûsâ alAsh'arî. The Prophet Muhammad was pleased to listen to his melodious recitation and told that his voice was blessed like the flute of the Prophet David (al-Nawâwî n.d., 84). This is because the sanctity of the Quran calls to virtue, not only does it relate to a certain meaning but also the beauty of the recitation. We can see that many Muslims show their aesthetic reception of the Quran either in spoken, written, and digital form in every chance and place they are in. This leads to the reception in the form of various recitations of the Quran so that its beauty will always be conveyed from time to time; and this also becomes the basis for those public figures to produce the online Quranic contents via Instagram.

\section{Picture 5}

Normative content and account owner's caption in Instagram

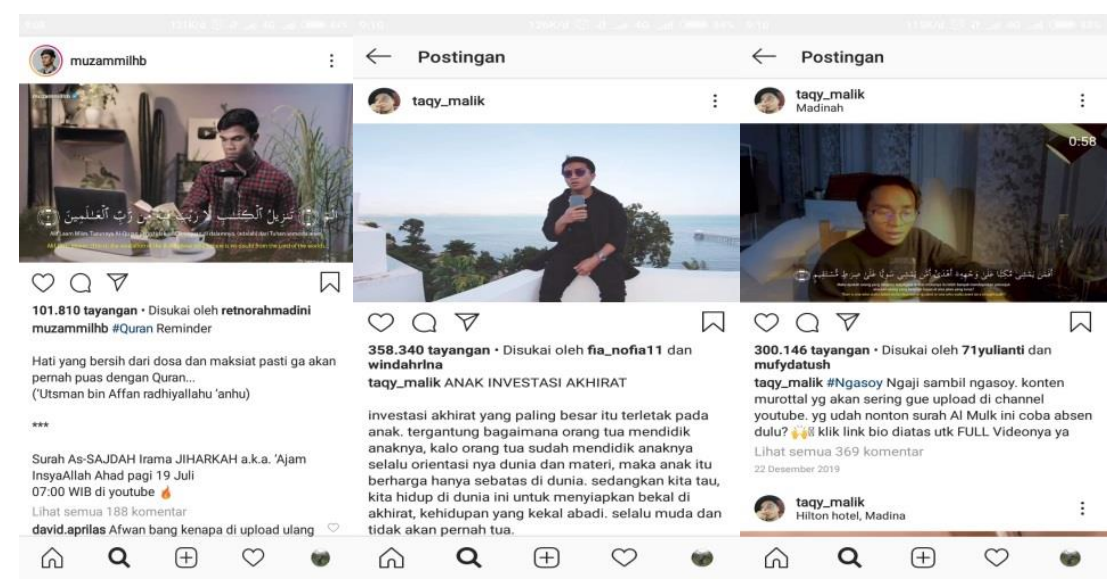

Instagram became one of popular applications and even almost every millennial person has the account. This is proven by various activities seen in Instagram. Instagram helps people interact easily and quickly with the help of visualized content such as photos, videos, etc. It has become an 
opportunity to widely and quickly spread the knowledge about the Quran. Moreover, people share the Quran's beauty by posting contents of recitation which are touching for its listeners/viewers. Looking at the amount of audiences, this proves that Indonesian society needs these kinds of contents.

\section{Historical Factors}

A beautiful recitation of the Quran in Instagram should be discussed along with other recitations from the very long time ago. With the development of the aforementioned social media, the beautiful recitation is widely spread. The content of the Quran recitation even becomes popular online.

Art wise, the beauty of reading is called nagam, which means the shaking of the entire joint in the body due to the touched heart (Ibn Manẓur 1994, 4491). Nagam can also be said as a process that produces beauty. It is also mentioned as a song or melody supporting the beauty of reading, in this case is the Quran (Nelson 2001, 64). It was initially only to embellish the reading of the Quran, unlike other cultural arts. Nagam is also considered as a technique of processing sound (al-Faruqi and al-Faruqi 2000, 491). Processing the sound beautifully gives comfort to the person who listens to it as well as convenient feeling in a person's heart. This is the thing which makes nagam develop along with the ever changing time.

The Arab society considers Nagam to be derived from Maqâmât al'Arabiyah which is always evolving (Masrurin 2019, 190). In Indonesia, maqam is translated as an Arabic melody related to the development of Arabic music art (Touma 1971). Arafat gives simple explanation by analogizing maqam as a well with water discharge as its nagam; variations and techniques are considered as process for obtaining water from the well (Arafat 2013, 21). Thus, the beauty of the Quran's recitation is the evolving variation following the changing taste, time, and trend. 
Picture 6

Historical content and account owner's caption in Instagram

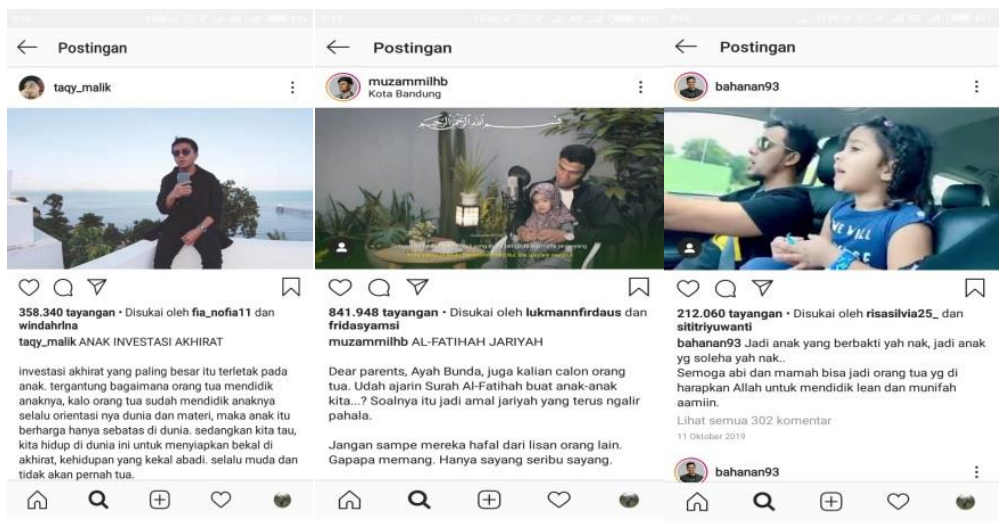

Data revealing the history side of the Quran's aesthetic reception is not that much. In general, it can be described as what has been explained by Ibn Manz̧ûr in Masrurin's work; first, the chants of infidel slaves who were imprisoned in a war against Muslims; second, nagam comes from the Arab ancestors' singing used to beautify the Quran's recitation (Masrurin 2019, 191). In addition, the Quran is taught orally and as the time goes by, the aesthetic reception is expanded to digital media or social media, including Instagram providing interactive features that make the Quran's teachers use it to get a response. This is eventually an effective way to preserve the beauty of the Quran. The different variants and ways attract and ease those who want to deepen their knowledge about the Quran anytime.

Those accounts posting the Quran's aesthetic reception follow the development of the Quran recitation so that their account also record the history seen through their content. This historical side makes these contents interesting because it provides historical lesson to other Instagram users.

\section{Social Factors}

Instagram is not only medium to present content through videos and photos, but also as a space to interact with other fellow Instagram users. This is done by accounts that provide the aesthetic reception of the Quran. Through those contents, they show theirtalent and expertise in reading the 
Quran to the followers and provide the chance to learning together, reminding each other, etc.

Social media give significant influence on artists in Indonesia who focus on the Quran, as recorded in the data and activities of both individual and communities on social media; and Instagram is the most preferable. The expressions contained in people's comments reveal various forms of aesthetic reception. Each account has its characteristics, so do the followers responding in the comment section. The response completes the two-way interaction both in the comment section and in a live broadcast. This shows that Instagram makes the users easier to read the Quran whereever and whenever. Interactions through Instagram are considered significant because they include a wide range, making it easier to interact with multiple people in unlimited time and place. No wonder does people nowadays access and search for Quran-related content in Instagram. They fulfill their need of Quranic content by visiting several popular accounts which have aesthetically pleasing contents.

The aesthetic reception of the Quran is the way to show the existence of the Quran itself. Every Muslim has their responsibility upon the holy book that he believes in, namely the Quran as a part of individual life that plays essential role in the social environment. The attitude and behaviour of people in reading the Quran on Instagram both murattal and mujawwad are part of the effort in establishing the existence of the Quran in social media space. A man who has a good voice reciting the Quran is obliged to share it with others so that people will get inspiration through the content. Instagram is used to disseminate the beauty of the Quran's recitation. The response and comments of people related also give the desire to learn and share about the Quran. 
Picture 7

Social Content and Account owner's caption in Instagram

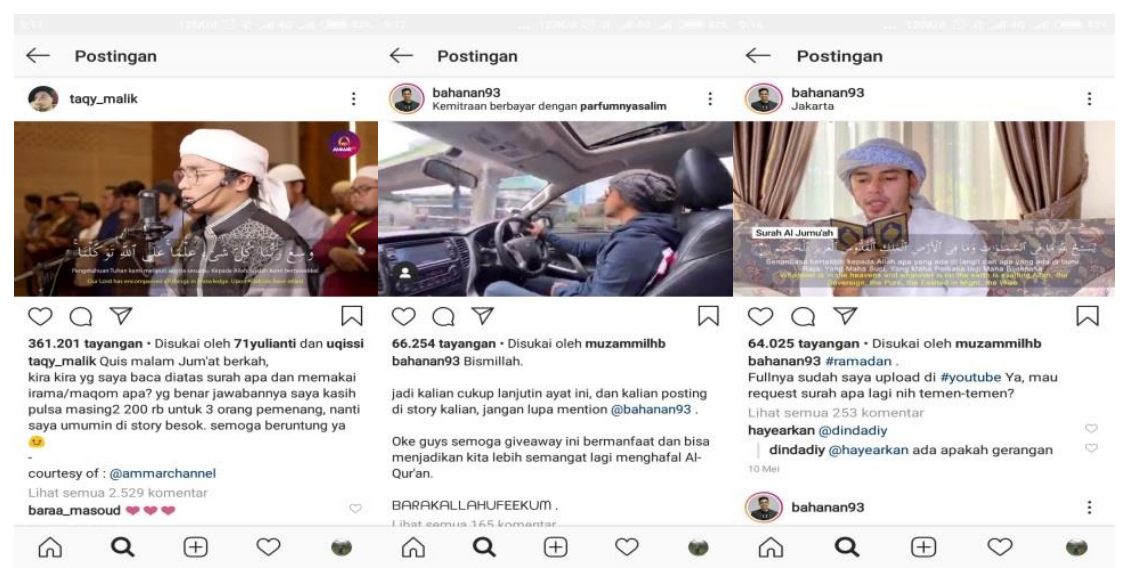

In some ways, there are some people who look narcissistic in uploading the Quran's recitation in Instagram. It is nevertheless not considered as narcissistic in general, since it is still a good thing. Religion does not prohibit the narcissistic behaviour but forbids riya (show off). People uploading their Quran recitation on Instagram aim at selfevaluation, which results in getting some corrections and comments from followers. This kind of interaction makes Instagram as a medium for improving the quality of reading. However, it also has a single authority site that allows its user to freely express them without any pressure. Hence, Instagram users have the authority to use their own space with various motives.

\section{Between the Reception of the Quran and Religious Commodification}

The existence of qâri's (reciter) accounts on Instagram does not only bring the aesthetic reception practice of the Quran into the culture of young people. More importantly, the accounts have brought traditional religious practices mixed with spiritual and political economy nuances. The Quran's reception done by the young qâri' attracts public's attention that results ingaining popularity. This fame gives legitimacy to the religious authority of these accounts and also boosts strong economy.

The Instagram account of young qâri' is used as a medium of da'wah by posting Quranic-related content targeting young audiences. Besides, the accounts also build internal market community. There are also political 
economic activities within the practicesincethey have the potential benefit through Instagram endorse system in collaboration with several brands that need promotion.

Picture 8

Religious Commodification Content on Instagram

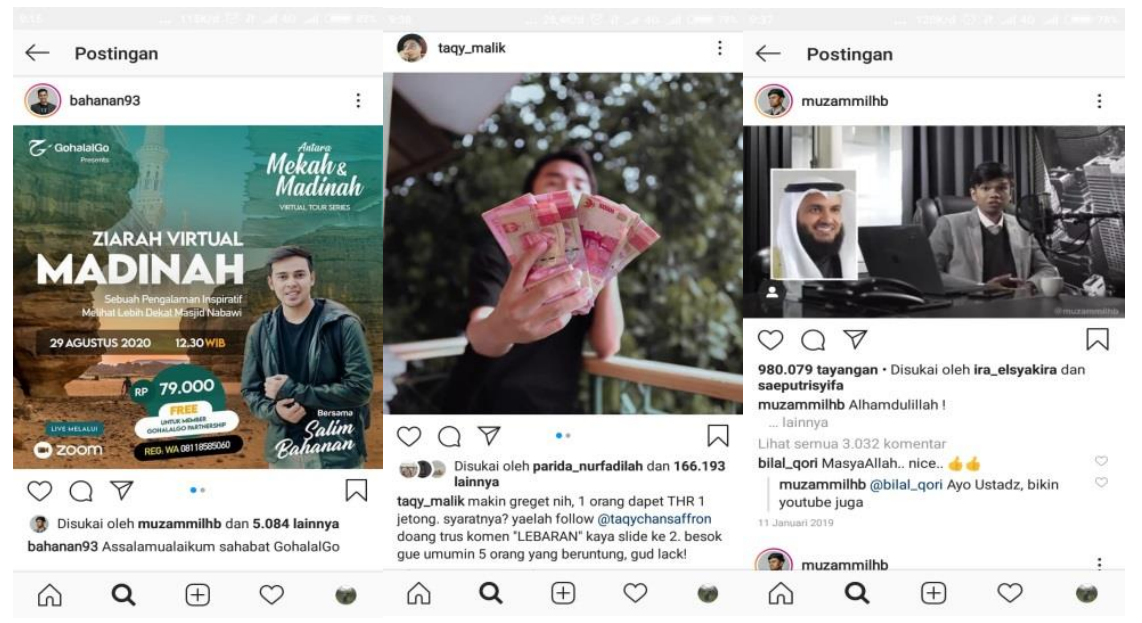

Taqy Malik himself has several businesses in various fields. All brands use his own names such as @QuranQube, a digital speaker media containing a collection of murattal al-Qur'ân recited by him. In the culinary field, he made@Taqychan.banana and @Taqychan.sambal; @taqychan.hijab in fashion field and @taqychantravel in the field of tour, travel, and tourism. All of them have their own Instagram accounts and are listed in taqy malik's Instagram account biography (I. L. Jannah 2020, 92).

Salim Bahanan also has several brands that are named after him. Among them is an Instagram online store called @bhnstore, which sells a variety of urban fabrics and fashions. Another is @brotherman_parfum that are traded men's perfumes online. Similarly, Boim has a t-shirt business which has quotes of Islamic content. Unlike Salim and Taqy, he does not name his brand with his own name, for example@iandm.co, his fashion product. He describes his efforts as da'wah in the field of youth fashion (I. L. Jannah 2020, 93).

It is widely known that Instagram is not only a medium for posting daily photos and videos but also a digital market with many economic 
transactions. Research conducted by Google and Temasek shows the value of online media transactions in Indonesia in 2028 will reach USD 2.7 Billion. One of the online markets is Instagram (transaksi Media Online Asia Tenggara Mencapai US\$11,4 Miliar pada 2018 | Databoks n.d.). This kind transaction has replaced face-to-face transaction. Online media with no face-to-face and no history of personal introduction is preferably done because digital world has significantly increased. So, achieving digital identity is needed, for the private sector and government (Sullivan 2018, 724).

\section{Conclusion}

Social media, including Instagram, which in reality is a space for interaction between society and the Quran, has shown the emergence of a reception practice. The Quran's aesthetic reception on Instagram is in the form of visualizations such as verse continuation feature and the practice of reading the Quran. This appearance is due to normative, historical, and social factors. Instagram modified the public reception of the Quran through various facilities and features. Young people initiated the appearance of an aesthetic reception of the Quran in this Instagram space as its primary users. Instagram became a new space for the Quran's receptions due to the high enthusiast of young people to express themselves, especially about showing their virtuous side and da'wah activities. It also raises economic commodities among Instagram public figures.

This study has at least revealed how dynamic the practice of the Quran's reception is in society shown in both real and virtual spaces. The results of this study are considered to have a significance about the discourse of Digital Qur'anic Studies, which is still lacking in attention. This kind of study has yet done by researchers, so it is still possible to do further study in the Quran's themes seen in social media (Instagram in particular), visualized Quranic verses that are in high demand, and in terms of mediatization aspect.

\section{References}

Ahmadi, Rizqa, Wildani Hefni, and Mutrofin Mutrofin. 2019. "Indonesian Global Ikhwan's Reception and Expression Toward Sunnah Polygamy in Online Media." Ulul Albab: Jurnal Studi Islam 20(1): 70-94. 
DOI: https://doi.org/10.18860/ua.v20i1.5660

al-Faruqi, Isma'il Raji, and Lois Ibsen al-Faruqi. 2000. Atlas Budaya Islam:

Menjelajah Khazanah Peradaban Gemilang. Trans. Ilyas Hasan. Bandung: Mizan.

Aminuddin, Ahsani Taqwim. 2017. "Instagram: Bingkai Kasus Agama di Media Sosial." Jurnal The Messenger 9(2): 163-75.

DOI: http://dx.doi.org/10.26623/themessenger.v9i2.403

Anderson, Jon W. 2003. "The Internet and Islam's New Interpreters." In New Media in the Muslim World: The Emerging Public Sphere, eds. Dale F. Eickelman and Jon W. Anderson. Bloomington: Indiana University Press, 45-60.

Annazilli, Haqqi. 2018. "Relasi Antara Agama dan Media Baru." Jurnal Ilmiah Syi'ar 18(2): 26-44.

DOI: http://dx.doi.org/10.29300/syr.v18i2.1677

Arafat, M. Yaser. 2013. "Tarekat Tilawatiyah: Melantunkan Al-Quran, Memakrifati Diri, Melakonkan Islam.” MA Theses. Postgraduate Program of Universitas Gajah Mada, Yogyakarta.

Aulia, Nisa Nur. 2017. "Islam dan Mediatisasi Agama." Communicatus: Jurnal Ilmu Komunikasi 1(1): 137-50.

Avifah, Nurul. 2017. "Efektivitas Dakwah Islam Melalui Sosial Media Instagram (Studi Akun Instagram Indonesia Menutup Aurat)." Jurnal Ilmiah Mahasiswa Raushan Fikr 6(2): 223-37.

DOI: http://dx.doi.org/10.24090/JIMRF.V6I2.2743

Becker, Carmen. 2009. "Gaining knowledge: Salafi activism in German and Dutch Online Forums.” Masaryk UJL EE Tech. 3(1): 79-98.

Budiargo, Dian. 2015. Berkomunikasi Ala Net Generation. Jakarta: Elex Media Komputindo.

Bunt, Gary R. 2003. Islam in the Digital Age: EJihad, Online Fatwas and Cyber Islamic Environments. London: Pluto Press.

Bunt, Gary R. 2009. Muslims: Rewiring the House of Islam. Chapel Hill: University of North Carolina Press. http://site.ebrary.com/id/10310782 (August 17, 2020). 
Dewi, Maya Sandra Rosita. 2019. "Islam dan Etika Bermedia (Kajian Etika Komunikasi Netizen di Media Sosial Instagram dalam Perspektif Islam)." Research Fair Unisri 3(1): 139-42.

DOI: http://dx.doi.org/10.33061/rsfu.v3i1.2574

Fadlillah, Nilna. 2019. "Resepsi Terhadap Alquran dalam Riwayat Hadis." Nun: Jurnal Studi Alquran dan Tafsir di Nusantara 3(2): 101-28.

DOI: http://dx.doi.org/10.32495/nun.v3i2.48

Fahrudin, Fahrudin. 2020. "Resepsi al-Quran di Media Sosial (Studi Kasus Film Ghibah dalam Kanal Youtube Film Maker Muslim)." Hermeneutik: Jurnal Ilmu Al-Quran dan Tafsir 14(1): 141-59.

DOI: http://dx.doi.org/10.21043/hermeneutik.v14i1.6890

Fathurrosyid, Fathurrosyid. 2016. "Tipologi Ideologi Resepsi Al Quran di Kalangan Masyarakat Sumenep Madura.” El Harakah: Jurnal Budaya Islam 17(2): 218-39.

DOI: https://doi.org/10.18860/el.v17i2.3049

Fauziah, Wiwi, and Miski Miski. 2019. "Al-Quran dalam Diskursus Toleransi Beragama di Indonesia.” Tajdid: Jurnal Ilmu Ushuluddin 18(2): $125-52$.

Gräf, Bettina. 2007. "Sheikh Yûsuf al-Qaradâwî in Cyberspace." Die Welt des Islams 47(3/4): 403-21.

Gräf, Bettina. 2009. Global Mufti: the Phenomenon of Yūsuf al-Qaradâwî. New York: Columbia University Press.

Graham, William Albert. 2001. Beyond the Written Word: Oral Aspects of Scripture in the History of Religion. Cambridge: Cambridge University Press.

Hamdan, Ali, and Miski Miski. 2019. "Dimensi Sosial dalam Wacana Tafsir Audiovisual: Studi atas Tafsir Ilmi, 'Lebah Menurut al-Quran dan Sains,' Lajnah Pentashihan Mushaf al-Quran Kemenag RI di Youtube." Religia: Jurnal Ilmu-ilmu Keislaman 22(2): 248-66.

DOI: https://doi.org/10.28918/religia.v22i2.2190

Handayana, Sri, and Muhamad Rezi. 2018. "MTQ; Antara Seni Membaca Alquran dan Politik Akomodasionis Pemerintah Terhadap Umat Islam." Islam Transformatif: Journal of Islamic Studies 2(2): 133-42. 
DOI: http://dx.doi.org/10.30983/it.v2i2.747

Hasan, Muhammad Zainul. 2020. "Resepsi Al-Quran Sebagai Medium Penyembuhan Dalam Tradisi Bejampi di Lombok.” Jurnal Studi Ilmuilmu Al-Quran dan Hadis 21(1): 133-52.

DOI: https://doi.org/10.14421/qh.2020.2101-07

Heryanto, Ariel. 2015. Identitas dan Kenikmatan. Jakarta: Kepustakaan Populer Gramedia.

Ibn Manẓûr, Jamâl al-Dîn. 1994. Lisân al'Arab. Beirut: Dâr al-Ṣâdir.

“Ibrohim Fadlannul Haq’s (@boim97) Profile on Instagram • 299 Posts.” https://www.Instagram.com/boim97/ (August 12, 2020).

Imron, Ali. 2019. "The Millenial Generation, Hadith Memes, and Identity Politics: The New Face of Political Contestation in Contemporary Indonesia." Ulul Albab: Jurnal Studi Islam 20(2): 255-83.

DOI: https://doi.org/10.18860/ua.v20i2.5675

Irwandani, Irwandani. 2016. "Potensi Media Sosial dalam Mempopulerkan Konten Sains Islam.” Tadris: Jurnal Keguruan dan Ilmu Tarbiyah 1(2): 173-77.

DOI: https://doi.org/10.24042/tadris.v1i2.1065

Iser, Wolfgang. 1978. The Act of Reading; A Theory of Aesthetic Response. Baltimore: John Hopkins University Press.

Ishaq, Ropingi el. 2013. "Dakwah di Tengah Industrialisasi Media." Jurnal Komunikasi Islam 3(1): 137-151.

DOI: https://doi.org/10.15642/jki.2013.3.1.\%25p

Ismail, Nurasiah, Zainal Abidin, and Uwes Fatoni. 2017. "Pesan Dakwah Tentang Nikah di Media Sosial Instagram.” Tabligh: Jurnal Komunikasi dan Penyiaran Islam 2(1): 22-45.

J. Boullata (ed), Issa. 2000. Literary Structures of Religious Meaning in the Quran. London: Routledge.

Jannah, Imas Lu'ul. 2018. "Resepsi Estetik Terhadap Alquran pada Lukisan Kaligrafi Syaiful Adnan.” Nun: Jurnal Studi Alquran dan Tafsir di Nusantara 3(1): 25-59.

DOI: https://doi.org/10.32459/nun.v3i1.14 
Jannah, Imas Lu'ul. 2020. "Qari Selebriti: Resitasi Alquran dan Anak Muda Muslim Indonesia di Era Media Sosial.” MA Theses. Universitas Islam Negeri Sunan Kalijaga Yogyakarta.

Jannah, Miftahul. 2017. "Musabaqah Tilawah Al-Quran di Indonesia (Festivalisasi Al-Quran Sebagai Bentuk Resepsi Estetis).” Jurnal Ilmiah Ilmu Ushuluddin 15(2): 87-95.

DOI: http://dx.doi.org/10.18592/jiu.v15i2.1291

“\#JuraganSaffron (@taqy_malik) - Instagram photos and videos.” https://www.Instagram.com/taqy_malik/(August 12, 2020).

Kamal, Muhamad Ali Mustofa. 2015. "Dinamika Struktur Kemukjizatan AlQur`an.” Syariati: Jurnal Studi Al-Quran dan Hukum 1(2): 189-212.

Kammer, Aske. 2012. "Adrienne Russell: Networked: A Contemporary History of News in Transition. Cambridge: Polity. 2011." MedieKultur: Journal of Media and Communication Research 28(53): 147 50 .

DOI: https://doi.org/10.7146/mediekultur.v28i53.7007

Khosim, Mochamad. 2019. "Resepsi Estetis Qurani dalam Musik Rock Sholawat Rofa Band di Bantul Yogyakarta.” Jurnal Studi Ilmu-ilmu AlQuran dan Hadis 20(2): 187-202.

DOI: https://doi.org/10.14421/qh.2019.2002-04

Larsson, Göran. 2016. Muslims and the New Media: Historical and Contemporary Debates. London: Routledge.

Lim, Merlyna. 2017. "Klik Yang Tak Memantik: Aktivisme Media Sosial di Indonesia." Jurnal Komunikasi Indonesia 3(1): 35-50.

DOI: https://doi/org/10.7454/jki.v3i1.7846

Lukman, Fadhli. 2018. "Digital Hermeneutics and A New Face of The Qur 'an Commentary: The Qur`an in Indonesian `s Facebook.” AlJami'ah: Journal of Islamic Studies 56(1): 95-120.

DOI: https://doi.org/10.14421/ajis.2018.561.95-120

Mahmudah, Nur. 2017. "Portraying Al-Quran in Cyber Media: Portrait in Social Media Facebook of Indonesian Muslim.” In French: Atlantis Press. https://www.atlantis-press.com/proceedings/icqhs17/25890938 (April 24, 2020). 
Mariani, Ermete. 2013. "Cyber-Fatwas, Sermons, and Media Campaigns: Amr Khaled and Omar Bakri Muhammad in Search of New Audiences." In Producing Islamic Knowledge: Transmission and Dissemination in Western Europe, eds. Martin van Bruinessen and Stefano Allievi. New York: Routledge, 154-80.

Masrurin, 'Ainatu. 2019. "Murattal dan Mujawwad Al-Quran di Media Sosial." Jurnal Studi Ilmu-ilmu Al-Quran dan Hadis 19(2): 188-202.

DOI: https://doi.org/10.14421/qh.2018.1902-04

Matondang, Ahmad Said. 2018. The Great of Reciting The Holy Qur'an. Tasikmalaya: Edu Publisher.

Miski, Miski, and Ali Hamdan. 2019. "Alquran dan Hadith dalam Wacana Delegitimasi Nasionalisme di Media Online Islam.” Al-A'raf: Jurnal Pemikiran Islam dan Filsafat 16(1): 25-48.

DOI: https://doi.org/10.22515/ajpif.v16i1.1644

Mustaqim, Abdul. 2015. Melihat Kembali Studi Alquran: Gagasan, Isu, dan Tren Terkini. Yogyakarta: Idea Press.

"Muzammil Hasballah - YouTube." https://www.youtube.com/channel/UC0sFBTGaDS8Ghsdw1iUcxa A (August 12, 2020).

"Muzammil Hasballah (@muzammilhb) • Instagram photos and videos." https://www.Instagram.com/muzammilhb/ (August 12, 2020).

Nasrullah, Rulli. 2011. "Konstruksi Identitas Muslim di Media Baru." Komunika: Jurnal Dakwah dan Komunikasi 5(2): 221-34.

DOI: https://doi.org/10.24090/KOMUNIKA.V5I2.172

Nasrullah, Rulli. 2016a. Media Sosial: Perspektif Komunikasi, Budaya, dan Sosioteknologi. Bandung: Simbiosa Rekatama Media.

Nasrullah, Rulli. 2016b. "Meme dan Islam: Simulakra Bahasa Agama di Media Sosial." Ilmu Dakwah: Academic Journal for Homiletic Studies 10(1): 113-28.

Nasrullah, Rulli. 2018. Komunikasi Antar Budaya di Era Budaya Siber. Jakarta: Prenada Media. 
al-Nawâwî, Abû Zakariyâ ibn Sharf. n.d. al-Tibyân fî Adâb Hamalat al-Qur'ân. Beirut: Dâr Ibn Hazm.

Nelson, Kristina. 2001. The Art of Reciting The Quran. Egypt: Cairo Press.

Nisa, Eva F. 2018. "Social Media and the Birth of an Islamic Social Movement: ODOJ (One Day One Juz) in Contemporary Indonesia." Indonesia and the Malay World 46(134): 24-43.

DOI: https://doi.org/10.1080/13639811.2017.1416758

Nurfuadah, Hilda. 2017. "Living Quran: Resepsi Komunitas Muslim Pada Alquran (Studi Kasus di Pondok Pesantren at-Tarbiyyatul Wathoniyyah Desa Mertapada Kulon, Kec. Astatana Japura, Kab. Cirebon)." Diya Al-Afkar: Jurnal Studi al-Quran dan al-Hadis 5(01): $125-$ 39.

DOI: https://doi.org/10.24235/diyaafkar.v5i01.4337

Nurhayati, Enung, Dedi Junaedi, and Sahliah Sahliah. 2019. "Dakwah Islam Melalui Karya Sastra.” Hanifiya: Jurnal Studi Agama-Agama 2(2): 105-12.

Pahala, Agam Akbar. 2018. "Resepsi Estetik Pada Lukisan Kaligrafi Sakban Yadi." Jurnal Tarbiyatuna 9(1): 1-17.

DOI: https://doi.org/10.31603/tarbiyatuna.v9i1.2067

"Penonton Video Digital Indonesia Diprediksi Mencapai 100 Juta Orang pada $2021 \quad$ Databoks.” https://databoks.katadata.co.id/datapublish/2018/12/06/penontonvideo-digital-indonesia-diprediksi-mencapai-100-juta-orang-pada-2021 (August 16, 2020).

Piela, Anna. 2013. Muslim Women Online: Faith and Identity in Virtual Space. New York: Routledge.

Prasetya, Anggia Nahla. 2019. "Resepsi Masyarakat Pada Alquran Sebagai Shifa' bagi Kesembuhan Pasien: Studi Living Quran di Rumah Sakit Islam Jemursari Surabaya." Undergraduate Theses. Universitas Islam Negeri Sunan Ampel Surabaya. http://digilib.uinsby.ac.id/38001/ (Juli 28, 2020). 
Putra, D. I. Ansusa. 2020. "Fitna' in Eveyday Life: Phenomena of the Digital Behavior of Indonesian Muslim Society on Dajjal Hadith.” Ulul Albab: Jurnal Studi Islam 21(1): 1-23.

DOI: https://doi.org/10.18860/ua.v21i1.7750

Rafiq, Ahmad. 2004. "Pembacaan yang Atomistik terhadap al-Quran: Antara Penyimpangan dan Fungsi." Jurnal Studi Ilmu-ilmu Al-Quran dan Hadis 5(1): 1-17.

Rafiq, Ahmad. 2014. "The Reception of the Quran in Indonesia: A Case Study of the Place of the Quran in a Non-Arabic Speaking Community." Ph. D. Dissertation. Temple University.

Rafiq, Ahmad. 2018. "Tradisi Resepsi al-Quran di Indonesia."

Rasmussen, Anne K. 2010. Women, the Recited Quran, and Islamic Music in Indonesia. Berkeley: University of California Press.

Riyadi, Fahmi. 2014. "Resepsi Umat atas Alquran: Membaca Pemikiran Navid Kermani Tentang Teori Resepsi Alquran." Hunafa: Jurnal Studia Islamika 11(1): 43-60.

DOI: https://doi.org/10.24239/jsi.v11i1.339.43-60

Romario, Romario, and Lisda Aisyah. 2019. "Komik Islam di Media Sosial Instagram: Dakwah Kreatif Melalui Komik." Islamuna: Jurnal Studi Islam 6(2): 98-119.

DOI: http://dx.doi.org/10.19105/islamuna.v6i2.2588

Rozaki, Abdur. 2013. "Komodifikasi Islam (Kesalehan dan Pergulatan Identitas di Ruang Publik).” Jurnal Dakwah 14(2): 199-212.

DOI: https://doi.org/10.14421/jd.2013.14203

Rozaq, Muhammad Fathur. 2019. "Pengaruh Meme Terhadap Identitas Pemuda Muslim Nusantara: Telaah Respons Konten Instagram.” Analisis: Jurnal Studi Keislaman 19(1): 193-210.

DOI: https://doi.org/10.24042/ajsk.v19i1.3030

Rurin, Aina Mas. 2018. "Resepsi Alquran dalam Tradisi Pesantren di Indonesia (Studi Kajian Nagham Alquran di Pondok Pesantren Tarbitayul Quran Ngadiluweh Kediri).” Al-Bayan: Jurnal Studi Ilmu AlQuran dan Tafsir 3(2): 101-118. 
"Salim Bahanan (@bahanan93) - Instagram Photos and Videos." https://www.Instagram.com/bahanan93/ (August 12, 2020).

Slama, Martin. 2018. "Practising Islam through Social Media in Indonesia." Indonesia and the Malay World 46(134): 1-4.

DOI: https://doi.org/10.1080/13639811.2018.1416798

Suardi, Suardi. 2016. "Antara Media Sosial dalam Komunikasi Politik." Jurnal Dakwah Risalah 27(2): 82-86.

DOI: http://dx.doi.org/10.24014/jdr.v27i2.2516

Sullivan, Clare. 2018. "Digital Identity - From Emergent Legal Concept to New Reality.” Computer Law E Security Review 34(4): 723-31.

DOI: https://doi.org/10.1016/j.clsr.2018.05.015

Suryati, Suryati. 2017. “Teknik Vokalisasi Seni Baca Al-Quran dalam Musabaqoh Tilawatil Quran.” Promusika: Jurnal Pengkajian, Penyajian, dan Penciptaan Musik 5(1): 47-52.

DOi: https://doi.org/10.24821/promusika.v5i1.2286

Suryati, Suryati, G. R. Lono L. Simatupang, and Victor Ganap. 2016. "Ornamentasi Seni Baca Al-Quran dalam Musabaqoh Tilawatil Quran sebagai Bentuk Ekspresi Estetis Seni Suara.” Resital: Jurnal Seni Pertunjukan 17(2): 67-74.

DOI: https://doi.org/10.24821/resital.v17i2.2219

Syamsuddin (ed.), Sahiron. 2012. Islam, Tradisi, dan Peradaban. Yogyakarta: Bina Mulia Press.

"Taqy

Malik YouTube." https://www.youtube.com/channel/UC1hCuHHCOD0Y2L1NjB6y 46w (August 12, 2020).

Touma, Habib Hassan. 1971. "The Maqam Phenomenon: An Improvisation Technique in the Music of the Middle East." Ethnomusicology 15(1): 38-48.

DOI: https://doi.org/DOI: 10.2307/850386

"Transaksi Media Online Asia Tenggara Mencapai US\$ 11,4 Miliar pada 2018 Databoks." https://databoks.katadata.co.id/datapublish/2018/12/05/transaksi- 
media-online-asia-tenggara-mencapai-us-114-miliar-pada-2018 (August 16, 2020).

Watie, Errika Dwi Setya. 2016. "Komunikasi dan Media Sosial (Communications and Social Media)." Jurnal The Messenger 3(2): 6974.

DOI: http://dx.doi.org/10.26623/themessenger.v3i2.270

Wibowo, Adi. 2019. "Penggunaan Media Sosial Sebagai Trend Media Dakwah Pendidikan Islam di Era Digital." Jurnal Islam Nusantara 3(2): 339-56.

DOI: https://doi.org/10.33852/jurnalin.v3i2.141

Zahra, Ulfa Fauzia, Ahmad Sarbini, and Asep Shodiqin. 2016. "Media Sosial Instagram Sebagai Media Dakwah.” Tabligh: Jurnal Komunikasi dan Penyiaran Islam 1(2): 60-88. 